\title{
BMJ
}

\section{Population screening for coeliac disease in primary care by district nurses using a rapid antibody test: diagnostic accuracy and feasibility study}

\author{
IIma R Korponay-Szabó, associate professor in paediatrics, ${ }^{1,2}$ Katalin Szabados, consultant paediatric \\ gastroenterologist, ${ }^{3}$ Jánosné Pusztai, district nurse, ${ }^{4}$ Katalin Uhrin, consultant pathologist, ${ }^{5}$ \\ Éva Ludmány, consultant pathologist, ${ }^{5}$ Éva Nemes, senior lecturer in paediatrics, ${ }^{1}$ Katri Kaukinen, senior \\ lecturer in gastroenterology, ${ }^{6}$ Anikó Kapitány, PhD student, ${ }^{7}$ Lotta Koskinen, PhD student, ${ }^{8}$ \\ Sándor Sipka, professor of immunology, ${ }^{7}$ Anikó Imre, director of the health officer service, ${ }^{4}$ \\ Markku Mäki, professor of paediatrics ${ }^{9}$
}

${ }^{1}$ Department of Paediatrics, Medical and Health Science Centre, University of Debrecen, 4032 Debrecen, Hungary

${ }^{2}$ Coeliac Disease Centre, Heim Pál Children's Hospital, 1089 Budapest, Hungary

${ }^{3}$ Department of Infectology, Hetényi Géza County Hospital, 5000 Szolnok, Hungary

${ }^{4}$ County Institute of Public Health and Health Officer Service, 5000 Szolnok, Hungary

${ }^{5}$ Department of Pathology, Hetényi Géza County Hospital, 5000 Szolnok, Hungary

${ }^{6}$ Department of Gastroenterology and Alimentary Tract Surgery, Tampere University Hospital and Medical School, 33014 Tampere, Finland

${ }^{7}$ Regional Immunology Laboratory, Third Department of Internal Medicine, Medical and Health Science Centre, University of Debrecen, 4032 Debrecen,

Hungary

${ }^{8}$ Department of Medical Genetics, Biomedicum Helsinki, University of Helsinki, 00014 Helsinki, Finland

${ }^{9}$ Paediatric Research Centre, Tampere University Hospital and Medical School, 33014 Tampere, Finland

Correspondence to: M Mäki markku.maki@uta.fi

doi:10.1136/bmj.39405.472975.80

\section{ABSTRACT \\ Objective To evaluate the feasibility and diagnostic accuracy of screening for coeliac disease by rapid detection of IgA antibodies to tissue transglutaminase performed in primary care.}

Design District nurses screened 6 year old children using rapid antibody testing of finger prick blood. They also collected capillary blood samples for laboratory determination of IgA and IgG antibodies to endomysium and IgA antibodies to tissue transglutaminase. Children with positive rapid test results were directly sent for biopsy of the small intestine.

Setting Primary care in Jász-Nagykun-Szolnok county, Hungary.

Participants 2690 children ( $77 \%$ of 6 year olds living in the county) and 120 nurses.

Main outcome measures Positivity for antibodies to endomysium or transglutaminase in the laboratory and coeliac disease confirmed at biopsy.

Results 37 children (1.4\%, 95\% confidence interval $0.9 \%$ to $1.8 \%$ ) had biopsy confirmed coeliac disease. Only five of these children had been diagnosed clinically before screening. Rapid testing had a $78.1 \%$ sensitivity $(70.0 \%$ to $89.3 \%$ ) and $100 \%$ specificity ( $88.4 \%$ to $100 \%$ ) for a final diagnosis of coeliac disease by biopsy. Sensitivity was $65.1 \%(50.2 \%$ to $77.6 \%)$ and specificity was $100 \%$ (99.8\% to $100 \%$ ) compared with combined results of IgA and IgG laboratory tests. Trained laboratory workers detected 30 of the 31 newly diagnosed IgA competent patients with the rapid test kit used blindly. Median time to biopsy after a positive rapid test result was significantly shorter (20 days, range 4-148) than after a positive laboratory result (142 days, 70-256; P<0.001). Children with coeliac disease detected at screening were smaller and had worse health status than their peers but they improved on a gluten-free diet.

Conclusions A simple rapid antibody test enabled primary care nurses to detect patients with coeliac disease in the community who were not picked up in clinical care. Extra training is needed to improve sensitivity.

\section{INTRODUCTION}

Coeliac disease is a genetically determined lifelong intolerance to gluten from dietary cereals; most people with coeliac disease have the human leucocyte antigen (HLA) types DQ2 or DQ8. ${ }^{2}$ In this disease, regular ingestion of wheat, rye, and barley induces $\mathrm{T}$ cell mediated inflammation in the gut and an autoimmune response to self proteins, mainly tissue (type 2) transglutaminase. ${ }^{1}$ As a result, the villous structure of the small bowel gradually deteriorates to a flat surface, ${ }^{3}$ but it can be fully restored by a gluten-free diet. ${ }^{2}$ Most patients who are diagnosed in the clinic have a combination of gastrointestinal symptoms and extraintestinal symptoms of variable severity. ${ }^{1}$ In addition, antibodies to tissue transglutaminase are present in the intestine and may also be deposited in other tissues. ${ }^{4}$ Evidence of malabsorption is not seen in all patients. Instead, the presenting clinical symptom can be itchy skin (dermatitis herpetiformis), osteoporosis, liver disease, kidney disease, cardiomyopathy, or infertility, and these symptoms can also be improved by diet. Furthermore, untreated coeliac disease predisposes to cerebellar ataxia; cancers, such as small intestinal adenocarcinomas and enteropathy associated $\mathrm{T}$ cell lymphomas; and autoimmune disorders (such as diabetes mellitus and thyroid diseases). However, these complications cannot be reversed by a gluten-free diet. ${ }^{2}$ Up to $90 \%$ of patients remain undiagnosed during childhood, as clinical symptoms may be absent or nonspecific for a long time. ${ }^{5}$

Detection of $\operatorname{IgA}$ autoantibodies in blood using purified tissue transglutaminase or tissue sections containing the antigen within endomysial or reticulin structures (endomysial antibody test) is recommended in symptomatic patients, ${ }^{7}$ in family members, and in high risk groups. ${ }^{2}$ Antibody tests have shown the 


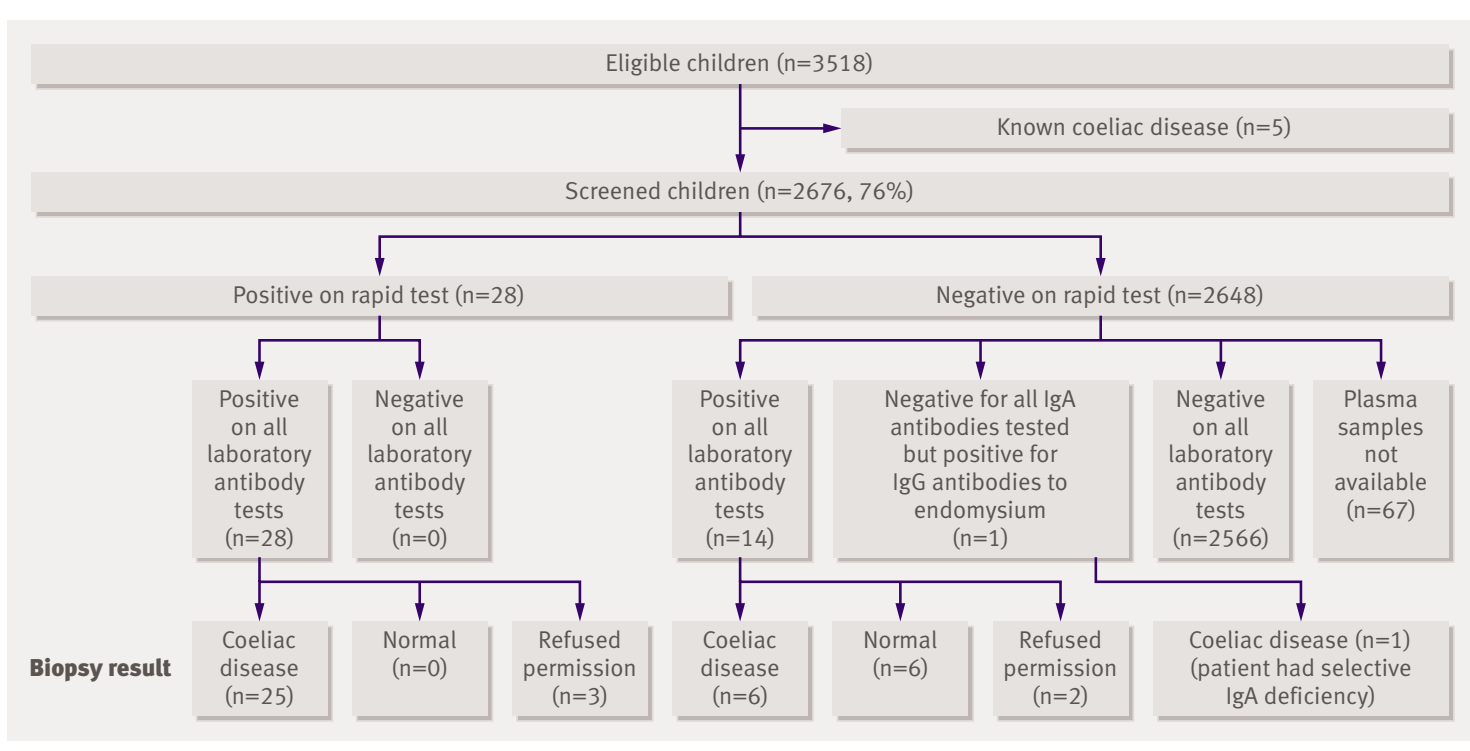

Fig 1 Study flow chart

prevalence of coeliac disease to be $0.3-1.2 \%$ in unselected European, North American, South American, and Indian populations. ${ }^{12}$ Although the burden of undiagnosed coeliac disease might be high ${ }^{13}$ and the disease is treatable, screening of the general population by venous blood sampling and conventional laboratory methods would be expensive, laborious, difficult to organise, and might not be acceptable to subjects. Rapid methods of antibody detection have recently become available that can be performed at the point of care using blood from finger pricks, ${ }^{14}$ and the point of care detection of IgA antibodies in coeliac disease has already been validated for clinical case finding in gastroenterology settings. ${ }^{16}$ In this study, we explore the feasibility of population screening for coeliac disease by means of a rapid antibody test performed by local healthcare workers in primary care.

\section{METHODS}

Subjects and screening procedure

We screened 6 year old children in Jász-NagykunSzolnok County, Hungary, which has a total of 413174 inhabitants. District nurses were asked to screen all children in their care born between 1 June 1998 and 31 May 1999, who were due to start school in 2005. These children had a preschool physical examination with weight and height measurements during the spring of 2005 at their primary care centre. Nurses measured antibodies to transglutaminase on site using $10 \mu \mathrm{l}$ of whole blood from a finger prick and a test that gives results in 5-10 minutes. Children with positive results on this rapid test were referred directly for small bowel biopsy to the paediatric gastroenterology unit of Hetényi Géza County Hospital, Szolnok, Hungary.

At the same time, the nurses collected $80 \mu \mathrm{l}$ of blood for the laboratory determination of IgA antibodies to endomysium and transglutaminase in plasma (the reference tests). These tests each have 95-98\% sensitivity and 98-99\% specificity for coeliac disease compared with biopsy of the small intestine. ${ }^{7}$ To increase sensitivity and ensure that we detected coeliac disease in IgA deficient children, we combined both tests and also measured IgG antibodies to endomysium in all samples. Children who were negative in all three laboratory tests were not investigated further, as they had a very low probability of having coeliac disease, and biopsy was considered unethical in such children.

The samples were number coded and sent to Heim Pál Children's Hospital, Budapest, Hungary. To check for correct sampling and to perform an interobserver comparison between the nurses and the laboratory, the nurses also submitted any diluted blood left over from the rapid test. Parents gave written informed consent to the blood sampling and screening. We sought separate consent for the confirmatory biopsy in children with positive test results.

\section{Rapid coeliac antibody testing}

Nurses used the Biocard coeliac disease test kit (AniBiotech) and evaluated results after five minutes but not later than 10 minutes, as instructed by the manufacturer. This immunochromatographic test detects IgA antibodies to tissue transglutaminase in whole blood with the aid of transglutaminase antigen contained within the erythrocytes in the sample being tested..$^{16}$ In brief, the blood sample is taken into a $10 \mu \mathrm{l}$ capillary, which is then inserted into a tube with haemolysing buffer to liberate the transglutaminase from the erythrocytes, and three drops are added to the test cassette. If antibodies against transglutaminase are present in the sample, they form immune complexes with endogenous transglutaminase and anti-IgA antibodies labelled with colloidal gold particles. The complexes bind to stationary reagents in the test membrane that capture transglutaminase to form a visible test line. A control line is included to check that blood and reagents have passed into the test area. The test result is positive if both the test line and control line

西 
are seen, negative if only the control line forms, and invalid if the control line is missing.

We gave the nurses written instructions for the test. More than $90 \%$ of the nurses also attended a 45 minute teaching session on coeliac disease, where the test kits were demonstrated using a clearly positive blood sample and blood from volunteers.

\section{Laboratory antibody testing of plasma}

At the screening session, the nurses took an additional $80 \mu \mathrm{l}$ of finger prick blood into a capillary tube (treated with ethylenediaminetetraacetate) that contained 100 $\mu \mathrm{l}$ of phosphate buffered saline. The sample was kept at $+4^{\circ} \mathrm{C}$ until its arrival at the laboratory within 36 hours. After centrifugation, the supernatant-comprising plasma diluted 1:2.5 with buffer-was used to investigate IgA and IgG antibodies to endomysium. The test consisted of a double colour indirect immunofluorescent method (green label for IgA and red label for IgG) that used composite blocks of monkey oesophagus and human appendix. ${ }^{17}$ Sample dilutions between 1:2.5 and 1:5 are internationally accepted to ensure high sensitivity. ${ }^{17}$ An endomysial or reticulin pattern of antibody binding on either substrate was considered to be a positive result; the antibody titre was established by performing further plasma dilutions.

IgA antibodies against transglutaminase were measured by the Celikey enzyme linked immunosorbent assay (Pharmacia Diagnostics); a result of $5 \mathrm{U} / \mathrm{ml}$ or greater was regarded as positive, as suggested by the manufacturer. Samples with values higher than the upper point of the standard curve were retested using appropriate dilutions. The laboratory tests were done without prior knowledge of the results of the rapid tests.

\section{Evaluation of small bowel biopsies}

Biopsy samples were taken by Watson capsule or during upper gastrointestinal endoscopy from the distal part of the duodenum. The ratio of the villous height to the crypt depth was calculated ${ }^{17}$ by evaluators who were blinded for the nature of the samples. A ratio of less than one was considered to be villous atrophy with crypt hyperplasia and indicative of untreated coeliac disease (Marsh grade III lesion). ${ }^{6}$ Frozen sections were used to investigate numbers of CD3 positive and $\gamma \delta$ positive intraepithelial lymphocytes and in situ deposition of antibodies to transglutaminase. ${ }^{18}$

\section{Clinical evaluation}

We determined the children's weight and height centiles using reference values for Hungarian children $^{19}$ and recorded any symptoms. We used standard laboratory methods to determine blood count and to measure serum iron, transferrin, and ferritin. HLA-DQ alleles were determined by polymerase chain reaction (GenoVision SSP kit; Qiagen Vertriebs $\mathrm{GmbH}$ ) in children with positive antibody tests. Parents of newly detected patients with coeliac disease and sex matched controls with negative antibody results answered a generic child health questionnaire, which had previously been validated in Hungarian children. ${ }^{20}$ We also asked the parents of patients with coeliac disease to answer the questionnaire after the children had spent six months on a gluten-free diet.

\section{Statistical analysis}

We calculated the sensitivity, specificity, positive predictive value, and negative predictive value of the rapid tests and compared them with those obtained for laboratory antibody tests and biopsy; 95\% confidence intervals were determined by the Wilson method. We compared median antibody titres before and after dietary treatment by means of the Wilcoxon signed ranks test. Haemoglobin values and body mass index before and after the gluten-free diet were compared by means of the paired t test.

\section{RESULTS}

\section{Screening results}

In total, 3518 births were registered in the county between 1 June 1998 and 31 May 1999. Of these children, $2690(76.5 \%)$ joined the study. Main reasons for non-participation were refusal of the parents $(7 \%)$ or nurses $(8 \%)$ and clashes between the nurses' working schedule and the children's summer holidays $(8.5 \%)$. The participating and non-participating children had similar demographic data. Five children (0.19\%) had previously been diagnosed with coeliac disease at 1.9, $2.3,2.4,2.7$, and 2.8 years of age. These children were on a gluten-free diet and were not screened. Another nine children were not screened because in the previous year they had tested negative for serum antibodies to endomysium. Thus, we screened 2676 children. Each of the 120 participating nurses screened a median of 18 children (range 4-95). Antibodies to

Table 1 Onsite rapid test for IgA antibodies to transglutaminase compared with laboratory tests for IgA and IgG antibodies to endomysium and IgA antibodies to transglutaminase

\begin{tabular}{|c|c|c|c|}
\hline \multirow[b]{2}{*}{ Laboratory test result } & \multicolumn{3}{|c|}{ Rapid test result } \\
\hline & Positive & Negative & Total \\
\hline $\begin{array}{l}\text { Positive serology result in the laboratory for any of the } \\
\text { antibodies tested }\end{array}$ & 28 & $15^{*}$ & 43 \\
\hline Negative antibody result in the laboratory & 0 & 2566 & 2566 \\
\hline Sample not available for laboratory evaluation & 0 & 67 & 67 \\
\hline Total & 28 & 2648 & 2676 \\
\hline
\end{tabular}

Sensitivity $65.1 \%$ (95\% confidence interval $50.2 \%$ to $77.6 \%$; specificity $100 \%$ ( $99.8 \%$ to $100 \%$ ).

${ }^{\star}$ One patient had selective IgA deficiency. 
transglutaminase were detected by onsite rapid testing in 28 children (1.05\%). No invalid tests were reported. The parents of 25 of these children consented to small bowel biopsy, and all children showed severe villous atrophy with crypt hyperplasia indicating coeliac disease. Median time from screening to biopsy was 20 days (4-148).

Capillary blood samples for laboratory testing were available from 2609 (97.5\%) of the screened children. $\mathrm{IgA}$ and $\mathrm{IgG}$ antibodies to endomysium were found in 42 specimens, and IgA antibodies to tissue transglutaminase were above the $5 \mathrm{U} / \mathrm{ml}$ cut-off level in 41 of these 42 specimens. One other sample was positive only for IgG antibodies to endomysium, but negative for all IgA autoantibodies. A jejunal biopsy and measurement of plasma total IgA showed that this patient had coeliac disease with selective IgA deficiency $(0.01 \mathrm{~g} / \mathrm{l})$. All 28 children who screened positive on site were also positive in laboratory tests for antibodies to endomysium (median titre 1:40, range 1:10-1:320) and transglutaminase (median $78.6 \mathrm{U} / \mathrm{ml}$, range 8.3-501). Antibody values in the other 14 children with IgA antibodies to endomysium were low or borderline (endomysium: 1:2.5, 1:2.5-1:40; transglutaminase: $10.5,3-63.2$ ) (fig 1). These 14 children were also invited to have a biopsy, and villous atrophy was found in six of the 13 children whose parents consented (fig 1). One procedure was unsuccessful by Watson capsule, and consent was not given for a second attempt by endoscopy. The villous architecture of the small bowel was normal in the other six children, even though their parents reported a normal intake of gluten. These six children had an HLA-DQ2 background, slightly raised numbers of intraepithelial lymphocytes (CD3 positive cells 45.3 cells/mm, range 36.6 to 53.9 , normal $<37 ; \gamma \delta$ positive cells 10.5 cells $/ \mathrm{mm}, 8.2$ to 12.7 , normal $<4.2$ ), and patchy deposition of transglutaminase antibodies in their small bowel specimens, but they did not fulfil the accepted diagnostic criteria of coeliac disease.

The median time from screening to biopsy was significantly longer (142 days, 70-256, $\mathrm{P}<0.001)$ in the children with positive antibody results in the laboratory only.

Coeliac disease was newly diagnosed in $32(1.2 \%)$ of the screened children, 24 girls and eight boys. Five other children had been diagnosed before screening, so the prevalence of biopsy confirmed coeliac disease in the investigated cohort was $1.38 \%(0.94 \%$ to $1.82 \%$; one in 73). The frequency of antibody positivity was $1.79 \%(1.29 \%$ to $2.30 \%)$.

Comparison of screening by nurses and in the laboratory Nurses (untrained evaluators) identified 25 of the 31 IgA competent children with coeliac disease who had villous atrophy. They also correctly evaluated 2566 negative samples and thus achieved $99.4 \%$ agreement with laboratory antibody test results (table 1). The positive predictive value of rapid testing was $100 \%$ $(99.8 \%$ to $100 \%)$ and the negative predictive value was $99.4 \%(99.0 \%$ to $99.7 \%)$. Table 2 compares the rapid test results with the final diagnosis of coeliac disease by biopsy; the positive predictive value was $100 \%(88.4 \%$ to $100 \%$ ). No negative predictive value for histology is available because we did not perform a biopsy on the 2566 children with a negative rapid test and negative laboratory antibody results. In children with a positive laboratory test result, the rapid test had a negative predictive value of $46.2 \%$ (23.2\% to $70.9 \%$ ).

The onsite rapid testing was less sensitive than the combined laboratory antibody tests. The diagnosis of coeliac disease could not be confirmed in 11 of the 43 antibody positive children, however, so the diagnostic efficiency of the rapid test was almost as high (99.3\%) as that of laboratory screening $(99.6 \%)$.

We also analysed sensitivity and specificity of the rapid test by counting the 67 samples that were not available for laboratory analysis as all positive or all negative - this gave a sensitivity of $34.5 \%(24.8 \%$ to $44.9 \%)$. Such a low sensitivity is unlikely, as the study was performed in a normal population with an expected 1-2\% prevalence of coeliac disease. Missing samples would not have affected specificity because all rapid test positive samples were available.

To establish whether the rapid test kit itself was less sensitive than the laboratory tests, we retested samples from the 31 children with coeliac disease who were positive for IgA antibodies to endomysium and 177 randomly selected children who were negative for these antibodies with the Biocard kit in a blinded fashion in two different laboratories (fig 2). All but one coeliac sample $(96.8 \%)$ were judged as positive when read by experts, but the positive test lines were often faint. In these cases, the line became clearer if the time to reading was increased to $10-15$ minutes. Also the dilutions prepared by the nurses gave positive rapid test results at the re-evaluation in all 27 available cases. Specificity was again $100 \%$ compared with the

Table 2 | Onsite rapid test for IgA antibodies to transglutaminase compared with final diagnosis of coeliac disease on the basis of laboratory antibody positivity (IgA and IgG) and biopsy of small intestine

\begin{tabular}{lccc} 
Biopsy result (all patients positive for laboratory & \multicolumn{2}{c}{ Rapid test result } \\
\cline { 2 - 4 } $\begin{array}{l}\text { antibody tests) } \\
\text { Villous atrophy indicative of coeliac disease }\end{array}$ & Positive & Negative & $7^{\star}$ \\
\hline Normal villous structure & 25 & 6 & 32 \\
\hline Biopsy not performed & 3 (refused biopsy) & 2635 & 2638 \\
\hline Total & 28 & 2648 & 2676 \\
\hline
\end{tabular}

Sensitivity $78.1 \%$ (95\% confidence interval $70.0 \%$ to $89.3 \%$ ); specificity $100 \%$ ( $88.4 \%$ to $100 \%$ ).

${ }^{\star}$ One patient had selective IgA deficiency. 


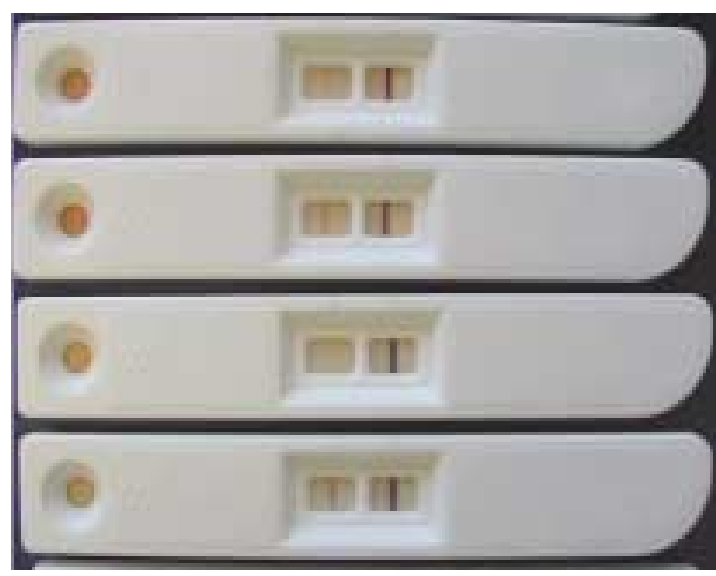

Fig 2 Retesting of screen detected patients at the laboratory using capillary blood samples collected by nurses. The blood sample diluted in buffer was applied to the round well on the left. Lines in the windows were evaluated after 10 minutes. The left window is the test window and the right one is the control window. All four samples were judged positive by a trained observer blinded to the previous results. The nurses evaluated the top three samples as negative and the bottom one as positive at initial screening

laboratory test results. These findings show that the rapid test is as sensitive as the laboratory tests and that the nurses made no major sampling errors. The lower sensitivity on site is probably caused by the nurses interpreting faint test lines as negative results.

\section{Clinical findings and response to treatment}

None of the 32 children diagnosed with coeliac disease after screening had been judged chronically ill or sent for investigation by the doctors who performed the routine physical preschool examination. Common clinical problems found in untreated coeliac disease were present in 27 of the 32 patients (table 3); 10 were underweight $(<10$ centiles), seven had iron deficiency anaemia (haemoglobin $<115 \mathrm{~g} / \mathrm{l}$ ), eight had low iron stores (serum ferritin $<14 \mu \mathrm{g} / \mathrm{l}$ ) without anaemia, and two had autoimmune thyroid disease. However, most of the other symptoms often occur in children without chronic disease.

Mean weight, height, and body mass index of children with screen detected coeliac disease were lower than those of their peers who were negative in the laboratory antibody tests (table 4). These children also scored lower in the generic health questionnaire for the items global general health, bodily pain, and general health perceptions, as reported by their parents (table 5).

We prescribed a gluten-free diet for all 32 children newly diagnosed with coeliac disease and re-evaluated them after six months. Median serum titres of antibody to endomysium decreased significantly from 1:40 to $1: 2.5(\mathrm{P}<0.0001)$ and median serum antibodies to transglutaminase decreased significantly from $56.5 \mathrm{U} /$ $\mathrm{ml}$ to $5.0 \mathrm{U} / \mathrm{ml}(\mathrm{P}<0.001)$. Mean haemoglobin values significantly increased from $120.7 \mathrm{~g} / 1$ to $128.0 \mathrm{~g} / \mathrm{l}$; $\mathrm{P}=0.0012$ ) and body mass index values increased from
14.7 to $15.3 ; \mathrm{P}<0.001)$. These changes were similar in children who were initially symptom free (data not shown). Parents reported less bodily pain and better general health compared with the period before screening (table 5).

\section{DISCUSSION}

Main findings

Coeliac disease is still largely underdiagnosed ${ }^{12}$ or diagnosed after a long delay, even when patients have symptoms. ${ }^{22}$ This study shows that a rapid method for near patient detection of coeliac disease antibodies is an efficient way to find new cases. Primary care nurses identified around $80 \%$ of patients with undiagnosed coeliac disease at the routinely performed preschool health check-up. To screen all children in a one year cohort in the county, each nurse performed around 20 rapid tests; this required little time and effort and fitted in with the nurses' normal working day. The rapid test seemed to be as accurate as laboratory testing and had a high positive predictive value and specificity. Some training is needed, however, to enable faint test lines to be recognised when circulating antibody concentrations are low. As with all visual tests, observer variability can affect the results, so the diagnosis should always be verified by histology. A rapid test used in primary care has advantages over conventional laboratory mass screening. It is simple, easy to organise, and the results are available at the screening session; these factors might improve compliance and reduce costs. ${ }^{23}$ Undiagnosed coeliac disease had negative effects on the children's health and development, but these effects were improved by a gluten-free diet.

\section{Primary care screening for coeliac disease}

These days, most patients are referred for diagnostic endoscopy and biopsy after positive serology. ${ }^{6}$ Primary care doctors should be aware of the most common symptoms - anaemia, delayed growth, fatigue, and minor gastrointestinal complaints ${ }^{12}$ - and appropriate training should increase the number of cases diagnosed..$^{25}$ Even so, most patients are still not detected until they are adults. Autoimmune manifestations; diabetes mellitus; osteopenia; and diseases of the skin, liver, brain, or other organs are common, often in the absence of gastrointestinal symptoms, ${ }^{1}$ and these patient groups are suggested targets for clinical case finding by serology. ${ }^{12}$ However, most of these features develop after the intestine has been affected for a long time, and they might be prevented if a diagnosis were made in childhood. ${ }^{26}$ A screening study in Finland identified coeliac autoantibodies in blood from schoolchildren several years before the disease was diagnosed clinically. ${ }^{8}$ Most children in our study with screen detected coeliac disease had some symptoms. Their parents did not seek medical help, however, and doctors did not identify them as having increased risk at the preschool examination, so they would not have been detected by case finding. The rapid screening test would identify most of these patients at an early age. 
This screening test could be performed with locally available personnel, without the need for special screening teams.

\section{Is population screening justified?}

Antibody tests can reliably identify patients with undiagnosed coeliac disease ${ }^{8}$ but screening is controversial because of doubts about its cost effectiveness, ${ }^{28}$ the reluctance of asymptomatic people picked up by screening to undergo biopsy and to follow dietary restrictions,${ }^{28}$ and the lack of proof of long term benefit to the community. ${ }^{23}$ However, the overall costbenefit balance may be favourable even when benefits are only moderate if screening is simple. Screening studies often have difficulty persuading people to undergo biopsy after the long time needed for the

\begin{tabular}{|c|c|c|c|c|c|}
\hline \multirow[b]{2}{*}{ Sex } & \multirow[b]{2}{*}{ Symptoms and signs } & \multirow[b]{2}{*}{$\begin{array}{l}\text { Ratio of villous height to } \\
\text { crypt depth on biopsy } \\
\text { (normal >2) }\end{array}$} & \multicolumn{3}{|c|}{ Detected by } \\
\hline & & & Rapid test & $\begin{array}{l}\text { IgA antibodies to } \\
\text { endomysium and } \\
\text { transglutaminase }\end{array}$ & $\begin{array}{l}\text { IgG antibodies to } \\
\text { endomysium }\end{array}$ \\
\hline $\mathrm{F}$ & Slow weight gain, pale stools, raised free T4 & 0.11 & Yes & Yes & Yes \\
\hline M & $\begin{array}{l}\text { Diarrhoea, slow weight gain, tiredness, } \\
\text { behavioural problems, frequent infections }\end{array}$ & 0.17 & Yes & Yes & Yes \\
\hline $\mathrm{F}$ & $\begin{array}{l}\text { Recurrent abdominal pain, raised } \\
\text { antibodies to thyroid antigens }\end{array}$ & 0.06 & Yes & Yes & Yes \\
\hline $\mathrm{F}$ & $\begin{array}{l}\text { Tiredness, constipation, behavioural } \\
\text { problems }\end{array}$ & 0.70 & Yes & Yes & Yes \\
\hline M & Twin A. Abdominal bloating & 0.25 & Yes & Yes & Yes \\
\hline $\mathrm{F}$ & Twin B. Slow weight gain, anaemia & 0.10 & Yes & Yes & Yes \\
\hline $\mathrm{F}$ & $\begin{array}{l}\text { Slow weight gain, abdominal bloating, } \\
\text { constipation, anaemia }\end{array}$ & 0.11 & Yes & Yes & Yes \\
\hline $\mathrm{F}$ & None & 0 & Yes & Yes & Yes \\
\hline $\mathrm{F}$ & $\begin{array}{l}\text { Recurrent abdominal pain, recurrent } \\
\text { obstructive bronchitis, anaemia }\end{array}$ & 0.08 & Yes & Yes & Yes \\
\hline M & Slow weight gain, bloating & 0.31 & Yes & Yes & Yes \\
\hline $\mathrm{F}$ & Chronic headache, anaemia & 0.26 & Yes & Yes & Yes \\
\hline $\mathrm{F}$ & $\begin{array}{l}\text { Diarrhoea, bloating, recurrent abdominal } \\
\text { pain }\end{array}$ & 0.08 & Yes & Yes & Yes \\
\hline $\mathrm{F}$ & $\begin{array}{l}\text { Recurrent diarrhoea, recurrent abdominal } \\
\text { pain }\end{array}$ & 0.24 & Yes & Yes & Yes \\
\hline $\mathrm{F}$ & None & 0.18 & Yes & Yes & Yes \\
\hline M & Slow weight gain, recurrent abdominal pain & 0.31 & Yes & Yes & Yes \\
\hline M & $\begin{array}{l}\text { Slow weight gain, bloating, steatorrhoea, } \\
\text { anaemia }\end{array}$ & 0.25 & Yes & Yes & Yes \\
\hline $\mathrm{F}$ & Slow weight gain, recurrent abdominal pain & 0.05 & Yes & Yes & Yes \\
\hline $\mathrm{F}$ & None & 0.47 & Yes & Yes & Yes \\
\hline M & $\begin{array}{l}\text { Bloating, recurrent abdominal pain, } \\
\text { tiredness, slow weight gain, frequent airway } \\
\text { infections }\end{array}$ & 0.33 & Yes & Yes & Yes \\
\hline $\mathrm{F}$ & $\begin{array}{l}\text { Slow weight gain, constipation, headache, } \\
\text { anaemia }\end{array}$ & 0.17 & Yes & Yes & Yes \\
\hline $\mathrm{F}$ & Recurrent abdominal pain, headache & 0.25 & Yes & Yes & Yes \\
\hline M & $\begin{array}{l}\text { Recurrent abdominal pain, delayed skeletal } \\
\text { age }\end{array}$ & 0.27 & Yes & Yes & Yes \\
\hline $\mathrm{F}$ & Dyspepsia & 0.40 & Yes & Yes & Yes \\
\hline $\mathrm{F}$ & None & 0.22 & Yes & Yes & Yes \\
\hline $\mathrm{F}$ & None & 0.20 & Yes & Yes & Yes \\
\hline$M$ & $\begin{array}{l}\text { Recurrent abdominal pain, chronic iron } \\
\text { replacement for recurrent anaemia }\end{array}$ & 0.20 & No & Yes & Yes \\
\hline $\mathrm{F}$ & Constipation & 0.35 & No & Yes & Yes \\
\hline $\mathrm{F}$ & $\begin{array}{l}\text { Abdominal bloating, raised liver } \\
\text { transaminases }\end{array}$ & 0.33 & No & Yes & Yes \\
\hline $\mathrm{F}$ & Slow weight gain & 0.15 & No & Yes & Yes \\
\hline $\mathrm{F}$ & Recurrent abdominal pain & 0.23 & No & Yes & Yes \\
\hline $\mathrm{F}$ & Slow weight gain & 0.26 & No & Yes & Yes \\
\hline $\mathrm{F}$ & $\begin{array}{l}\text { Slow weight gain, recurrent abdominal pain, } \\
\text { headache, anaemia, selective IgA } \\
\text { deficiency }\end{array}$ & 0.09 & No & No & Yes \\
\hline
\end{tabular}


Table 4 Growth of 6 year old children diagnosed with coeliac disease at screening and their healthy counterparts. Values are mean ( $95 \%$ confidence interval)

\begin{tabular}{|c|c|c|}
\hline Measure & $\begin{array}{l}\text { Children with coeliac } \\
\text { disease }(n=32)\end{array}$ & $\begin{array}{l}\text { Antibody negative children } \\
\qquad(\mathrm{n}=2566)\end{array}$ \\
\hline \multicolumn{3}{|c|}{ Height $(\mathrm{cm})$} \\
\hline Boys & $114.2(110.8 \text { to } 117.6)^{*}$ & 120.0 (119.8 to 120.2$)$ \\
\hline Girls & 116.1 (112.9 to 119.3$)$ & 119.3 (119.0 to 119.5$)$ \\
\hline \multicolumn{3}{|c|}{ Weight (kg) } \\
\hline Boys & $18.1(16.25 \text { to } 19.9)^{\star \star \star}$ & $23.4(23.2$ to 23.6$)$ \\
\hline Girls & 20.7 (19.3 to 22.1) & 22.7 (22.5 to 22.8$)$ \\
\hline \multicolumn{3}{|c|}{ Body mass index $\left(\mathrm{kg} / \mathrm{m}^{2}\right)$} \\
\hline Boys & $13.8(12.9 \text { to } 14.8)^{\star \star}$ & 16.1 (16.0 to 16.3$)$ \\
\hline Girls & 15.3 (14.8 to 15.8$)$ & 15.8 (15.7 to 15.9$)$ \\
\hline
\end{tabular}

laboratory evaluation. ${ }^{2}$ With the rapid screening test, nurses immediately notified the parents about a positive test result and less than $10 \%$ refused to give their permission. The time to biopsy was also significantly shorter after an onsite positive result than after a positive result received from the laboratory. We did not ask about the patients' preferences regarding blood sampling methods, as nurses would not have been able to collect venous blood samples from the children. These young children tolerated sampling from a finger prick, so we anticipate that this method would be acceptable for most people.

After six months on a gluten-free diet, serum autoantibody values fell at the expected rate in all but two of the newly diagnosed patients, which indicates good short term dietary compliance. Growth also improved and haemoglobin concentrations increased in children whose parameters were initially not pathologically low. In addition, parents reported less bodily pain and improved self esteem, so treatment clearly improved the children's health status. Chronic gastrointestinal disorders and anaemia probably affect academic performance, and young adults with undetected coeliac disease tend to underachieve at degree level. ${ }^{29}$ Thus, early detection of coeliac disease may be important for both the individual and society. However, we still do not know whether people with seropositivity but with preserved villous structure need treatment. $^{8}$

\section{Implications for screening policy}

The best age for screening is debatable. Disease specific antibodies appear in the serum around the age of $2-3$ years,${ }^{30}$ and family members of Hungarian patients rarely developed seropositivity after the age of $6 .{ }^{31}$ In our study, prevalence at age $6(1.4 \%)$ was higher than in most European studies of older children and adults. ${ }^{2}$ Thus, most patients can already be identified at this age, and dietary compliance is likely to be better in these young children than in teenagers. Rapid testing can also be used to retest children who develop suspicious symptoms later.

Several combinations of antibody tests have already been evaluated for population screening purposes. ${ }^{34}$ In general, high sensitivity is preferred over high specificity, ${ }^{23}$ but such tests often generate a high number of false positive results when the condition has a low probability. ${ }^{32}$ The diagnosis of coeliac disease requires biopsy of the small intestine, so the number of unnecessary and costly endoscopy procedures should be kept as low as possible. Our results indicate that one step rapid detection of antibodies to transglutaminase had high positive predictive value for the presence of intestinal lesions. Rapid test results also agreed equally well with the conventional laboratory tests as different laboratory antibody tests agreed in clinical settings. ${ }^{35}$ The sensitivity of the rapid test was only around $80 \%$, and the test missed the seropositive cases without

$\overline{\text { Table } 5 \text { | Results of child health questionnaire. Values are mean score ( } 95 \% \text { confidence intervals) on a scale of } 0-100 \text {; higher values }}$ indicate better health ${ }^{21}$

Children with coeliac disease

\begin{tabular}{|c|c|c|c|}
\hline \multirow[b]{2}{*}{ Scored item } & \multicolumn{2}{|c|}{ Children with coeliac disease } & \multirow[b]{2}{*}{$\begin{array}{l}\text { Children with no antibodies to } \\
\text { endomysium }(\mathrm{n}=80)\end{array}$} \\
\hline & Before gluten-free diet $(n=28)$ & $\begin{array}{l}\text { After } 6 \text { months of gluten-free diet } \\
\qquad(n=27)\end{array}$ & \\
\hline Global general health & $58.9(50.4 \text { to } 67.4)^{*}$ & $71.1(64.9$ to 77.3$) \dagger$ & 75.8 (71.6 to 80.0$)$ \\
\hline Physical functioning & 95.6 (91.3 to 100$)$ & 97.1 (93.5 to 100$)$ & 95.4 (93.0 to 97.9$)$ \\
\hline Role-social limitations, behavioural & 85.9 (74.8 to 97.0$)$ & 84.0 (72.7 to 95.2$)$ & 94.2 (90.7 to 97.7$)$ \\
\hline Role-social limitations, physical & 93.8 (87.9 to 99.8$)$ & 91.4 (83.1 to 99.5$)$ & $91.9(87.7$ to 96.1$)$ \\
\hline Bodily pain & $54.3(44.4 \text { to } 64.1)^{\star}$ & $75.6(68.2$ to 82.9$) \ddagger$ & 82.2 (78.8 to 85.7$)$ \\
\hline Behaviour & $65.3(60.1$ to 70.4$)$ & $67.0(59.6$ to 74.4$)$ & $70.7(67.8$ to 74.5$)$ \\
\hline Global behaviour & $70.0(61.9$ to 78.1$)$ & $67.9(60.2$ to 75.5$)$ & 73.5 (69.6 to 77.4$)$ \\
\hline Mental health & 85.7 (79.9 to 91.5$)$ & $86.2(80.7$ to 91.8$)$ & $88.6(86.1$ to 91.2$)$ \\
\hline Self esteem & $68.2(59.2$ to 77.1$)$ & $75.3(67.1$ to 83.5$)$ & 76.9 (72.7 to 81.2$)$ \\
\hline General health perceptions & $57.9(49.1 \text { to } 66.7)^{\star}$ & $60.5(53.6 \text { to } 67.4)^{*}$ & $75.2(71.2$ to 79.2$)$ \\
\hline Parental impact, emotional & $65.2(56.0$ to 74.4$) \S$ & $63.9(54.3$ to 73.6$) \S$ & 75.4 (71.0 to 79.7$)$ \\
\hline Parental impact, time & 81.6 (70.1 to 93.0$)$ & 81.7 (71.9 to 94.4$)$ & $86.7(82.3$ to 91.0$)$ \\
\hline Family activities & 81.7 (72.5 to 90.9$)$ & 83.7 (75.5 to 91.9$)$ & $84.2(80.1$ to 88.4$)$ \\
\hline Family cohesion & 66.3 (57.0 to 75.6$)$ & 67.2 (58.6 to 75.8$)$ & $67.3(62.0$ to 72.7$)$ \\
\hline
\end{tabular}

* $P=0.001$ compared with antibody negative peers; $\uparrow P=0.02$ compared with untreated children with coeliac disease; $¥ P<0.001$ compared with untreated children with coeliac disease; $\S \mathrm{P}=0.02$ compared with antibody negative peers. 


\section{WHAT IS ALREADY KNOWN ON THIS TOPIC}

Coeliac disease is difficult to recognise in primary care because symptoms can be non-specific or absent

Assays to detect disease specific antibodies in blood are suitable for case finding and screening

Proposals for screening have been criticised for being costly, difficult to organise, and of uncertain benefit

\section{WHAT THIS STUDY ADDS}

We describe a simple, rapid, and cheap method for detecting IgA antibodies that enabled primary care nurses to recognise most undiagnosed patients with coeliac disease at age 6

Screen detected patients had worse health status than peers, but this improved after treatment

villous atrophy. However, the nurses had not received training and were relatively inexperienced-the data came from the first 15-30 tests that they performed. Most patients who were not picked up by the onsite test had low antibody titres (1:2.5), which are difficult to recognise even for many clinical laboratories. The design of the study may have caused further confounding-nurses sent all patients with positive results directly for endoscopy, and they may have been reluctant to do this if the test line was faint. The expert readers' results show that training could greatly improve sensitivity. In theory, this might reduce specificity, although this did not happen here. Selective IgA deficiency can also complicate serological detection of some rare cases of coeliac disease, both in clinical and screening settings. ${ }^{17}$ The rapid test would, in principle, be suitable to measure both IgA and IgG antibodies to transglutaminase, and this problem might be solved in the future by commercial kits that measure both classes of antibody.

\section{Cost effectiveness and limitations}

Screening an adult population for coeliac antibodies would be cost saving in the long term. ${ }^{34}$ Onsite rapid testing using blood from a finger prick does not need complicated logistics, extra personnel for venous blood sampling, sample transportation and blood separation, or laboratory facilities. We anticipate that screening protocols based on these rapid tests will be more cost effective than the laboratory based testing, although the cost of the test kit and that of the nurses' time will vary in different countries.

The Biocard coeliac disease test cost around $€ 10$ ( $£ 7$; $\$ 14.5)$ from pharmacies in 2005 in Hungary. However prices for large scale screening might be much lower. Further studies are needed to evaluate the costs in relation to the prevention of late complications.

\section{Conclusions}

A simple rapid test performed in primary care at the preschool check-up identified most undiagnosed cases of coeliac disease in the community. Such a procedure could easily be adopted in countries with more limited financial resources. Early treatment may help improve the quality of life of affected people in the long term.
Thanks to all participating nurses, families, and primary care doctors. Thanks also to Andrásné Jordán, Hajnalka Bata, Erzsébet Nagy, Lászlóné Nagy, and Beatrix Barabás for technical help.

Contributors: IRK-S designed the study, evaluated serological results, and wrote the manuscript with the help of the other authors. KS performed the biopsies, the clinical evaluation, and follow-up of patients identified by screening. JP and Al organised the screening and collected the data from the nurses. KU and ÉL performed the histological evaluation of the biopsies. ÉN evaluated the clinical data and helped in the statistical analysis. KK performed the immunohistochemistry. AK, SS, and LK helped with HLA testing. MM helped design the study, evaluate the data, and prepare the manuscript. IKR-S is guarantor.

Funding: The Hungarian Scientific Research Fund (OTKA K61868), the Hungarian Ministry of Health (ETT518/2003), the Research Fund of Tampere University Hospital, and an EU Marie Curie mobility grant (MRTN CT-2006-036032; TRACKS). Ani-Biotech, Vantaa, Finland provided the rapid test kits free of charge but did not sponsor the study in any other ways.

Competing interests: MM and IRK-S are the inventors of the patent application "Methods and means for detecting gluten-induced disease" (PCT/FIO2/00340, international publication number W002/086509 A19). Finn Medi Research (owned by Tampere University and Tampere University Hospital, Finland) has commercialised the innovation and licensed it to Ani Biotech, which used it to develop the Biocard coeliac test. FinnMedi Research and Ani Biotech were not involved in this study. Ethical approval: Ethical committee of Heim Pál Children's Hospital (permission IKEB 30/2005)

1 Green PH, Jabri B. Coeliac disease. Lancet 2003;362:383-91.

2 Van Heel DA, West J. Recent advances in coeliac disease. Gut 2006;55:1037-46

3 Lähdeaho ML, Kaukinen K, Collin P, Ruuska T, Partanen J, Haapala AM, et al. Celiac disease: from inflammation to atrophy: a long-term follow-up study. J Pediatr Gastroenterol Nutr 2005;41:44-8.

4 Korponay-Szabó IR, Halttunen T, Szalai Z, Laurila K, Király R, Kovács JB, et al. In vivo targeting of intestinal and extraintestinal transglutaminase 2 by coeliac autoantibodies. Gut 2004;53:641-8.

5 Ravikumara M, Nootigattu VKT, Sandhu BK. Ninety percent of coeliac disease is being missed.J Pediatr Gastroenterol Nutr 2007;45:497-9.

6 Hopper AD, Cross SS, Hurlstone DP, McAlindon ME, Lobo AJ, Hadjivassiliou M, et al. Pre-endoscopy serological testing for coeliac disease: evaluation of a clinical decision tool. BM/ 2007:334:729.

7 Rostom A, Dube C, Cranney A, Saloojee N, Sy R, Garritty C, et al. The diagnostic accuracy of serologic tests for celiac disease: a systematic review. Gastroenterology 2005;128(4 suppl 1):S38-46.

8 Mäki, Mustalahti K, Kokkonen J, Kulmala P, Haapalahti M, Karttunen T, et al. Prevalence of celiac disease among children in Finland. N Englj Med 2003;348:2517-24.

9 Bingley PJ, Williams AJ, Norcross AJ, Unsworth DJ, Lock RJ, Ness AR, et al. Undiagnosed coeliac disease at age seven: population based prospective birth cohort study. BMJ 2004;328:322-3.

10 West J, Logan RF, Hill PG, Lloyd A, Lewis S, Hubbard R, et al. Seroprevalence, correlates, and characteristics of undetected coeliac disease in England. Gut 2003;52:960-5.

11 Sood A, Midha V, Sood N, Avasthi G, Sehgal A. Prevalence of celiac disease among school children in Punjab, North India. J Gastroenterol Hepatol 2006;21:1622-5.

12 Fasano A, Berti I, Gerarduzzi T, Not T, Colletti RB, Drago S, et al. Prevalence of celiac disease in at-risk and not-at-risk groups in the United States: a large multicenter study. Arch Intern Med 2003;163:286-92

13 Metzger MH, Heier M, Mäki M, Bravi E, Schneider A, Löwel H, et al. Mortality excess in individuals with elevated IgA antitransglutaminase antibodies: The KORA/MONICA Augsburg cohort study 1989-1998. Eur J Epidemiol 2006;21:359-65.

14 Korponay-Szabó IR, Raivio T, Laurila K, Opre J, Király R, Kovács JB, et al. Coeliac disease case finding and diet monitoring by point-of-care testing. Aliment Pharmacol Ther 2005;22:729-37.

15 Raivio T, Kaukinen K NemesÉ, Laurita K, Collin P Kovács JB, et al. Self transglutaminase-based rapid coeliac disease antibody detection by a lateral flow method. Aliment Pharmacol Ther 2006;24:147-54.

16 Nemec G, Ventura A, Stefano M, Di Leo G, Baldas V, Tommasini A, et al. Looking for celiac disease: diagnostic accuracy of two rapid commercial assays. Am J Gastroenterol 2006;101:1597-600.

17 Korponay-Szabó IR, Kovács J, Czinner A, Gorá CZG, Vámos A, Szabó T, et al. High prevalence of silent celiac disease in preschool children screened with IgA/IgG antiendomysium antibodies. J Pediatr Gastroenterol Nutr 1999;28:26-30.

18 Jäninen T, Kaukinen K, Laurila K, Kyrönpalo S, Rasmussen M, Mäki M, et al. Intraepithelial lymphocytes in celiac disease. Am J Gastroenterol 2003;98:1332-7. 
19 Darvay S, Ágfalvi R, Joubert K. Reference values for investigation of growth and development of Hungarian children aged 0-10 years. [In Hungarian.] Anonymus Kiadó Budapest , 1997.

20 Orbán I, Ruperto N, Balogh Z. The Hungarian version of the childhood health assessment questionnaire (CHAQ) and the child health questionnaire (CHQ). Clin Exp Rheumatol 2001;19:S81-5.

21 Landgraf JM, Abetz L, Ware JE. The CHQ user's manual. Second Printing, Boston, MA: HealthAct, 1999.

22 Zipser RD, Patel S, Yahya KZ, Baisch DW, Monarch E. Presentations of adult celiac disease in a nationwide patient support group. Dig Dis SC 2003;48:761-4.

23 Mearin ML, Ivarsson A, Dickey W. Coeliac disease: is it time for mass screening? Review. Best Pract Res Clin Gastroenterol 2005;19:441-52.

24 Hin H, Bird G, Fisher P, Mahy N, Jewell D. Coeliac disease in primary care: case finding study. BMJ 1999;318:164-7.

25 Berti I, Della Vedova R, Paduano R, Devetta M, Caradonna M, Villanacci $V$, et al. Coeliac disease in primary care: evaluation of a case-finding strategy. Dig Liver Dis 2006;38:461-7.

26 Ventura A, Magazzu G, Greco L. Duration of exposure to gluten and risk for autoimmune disorders in patients with celiac disease. SIGEP Study Group for Autoimmune Disorders in Celiac Disease. Gastroenterology 1999;117:297-303.

27 Fasano A. European and North American populations should be screened for coeliac disease. Protagonist. Gut 2003;52:168-9.

28 Kumar PJ. European and North American populations should be screened for coeliac disease. Antagonist. Gut 2003;52:170-1.
29 Verkasalo MA, Raitakari OT, Viikari J, Marniemi J, Savilahti E. Undiagnosed silent coeliac disease: a risk for underachievement? Scand J Gastroenterol 2005;40:1407-12.

30 Simell S, Kupila A, Hoppu S, Hekkala A, Simell T, Ståhlberg MR, et al. Natural history of transglutaminase autoantibodies and mucosal changes in children carrying HLA-conferred celiac disease susceptibility. Scand J Gastroenterol 2005;40:1182-91.

31 Korponay-Szabó IB, Kovács J, Lőrincz M, Török E, Gorácz G. Families with multiple cases of gluten-sensitive enteropathy. Z Gastroentero 1998;36:553-8.

32 Corrao G, Corazza GR, Andreani ML, Torchio P, Valentini RA, Galatola G, et al. Serological screening of coeliac disease: choosing the optimal procedure according to various prevalence values. Gut 1994;35:771-5.

33 Tommasini A, Not T, Kiren V, Baldas V, Santon D, Trevisiol C, et al. Mass screening for coeliac disease using antihuman transglutaminase antibody assay. Arch Dis Child 2004;89:512-5.

34 Shamir R, Hernell O, Leshno M. Cost-effectiveness analysis of screening for celiac disease in the adult population. Med Decis Making 2006;26:282-93.

35 Tesei N, Sugai E, Vazquez H, Smecuol E, Niveloni S, Mazure R, et al. Antibodies to human recombinant tissue transglutaminase may detect coeliac disease patients undiagnosed by endomysial antibodies. Aliment Pharmacol Ther 2003;17:1415-23.

Accepted: 8 October 2007 